\title{
THE PSYCHOLOGICAL FACTOR OF THE COMPANIES AND THEIR EFFECT ON THE NAIRU AND ECONOMIC CYCLE IN SLOVAKIA
}

\author{
Emilie Jašová ${ }^{1}$ \\ ${ }^{1}$ University of Economics, nám. W. Churchilla 1938/4, 13067 Prague 3, Czech Republic, \\ ekonomka_2@hotmail.com
}

\begin{abstract}
The paper analyses the uncertainties in postmodern or post-industrial or information society. It outlines the methods that are commonly used for measuring the effect of cognitive processes on decision-making and creating anomalies and uncertainties in general. It submits a Central European parallel to the VIX fear and uncertainty index used in America. It puts several demand shocks in the standard Gordon's Triangle model for estimating inflation according to S. Sekhon. The Kalman filter method compares the values of the NAIRU and economic cycle without and with the effect of the psychological factor among companies. We outline five scenarios that map the relationship between the uncertainty perception among companies and unemployment rate. A detailed analysis quantifies the intensity of the effect of the estimated psychological factor on the supply side on the unemployment rate. It outlines the consequences for the policymakers whose policies support spilling over the positive expectations in economy.
\end{abstract}

\section{Keywords}

Index of uncertainty perception among companies, Phillips curve, NAIRU, Kalman filter, unemployment gap

\section{JEL Classification}

E24, E32, E33, E37

DOI: https://doi.org/10.14311/bit.2019.01.05

Editorial information: journal Business \& IT, ISSN 2570-7434, CreativeCommons license (c) () published by CTU in Prague, 2019, http://bit.fsv.cvut.cz/ 


\section{Introduction}

According to Bělohradský (2013), the modernity is characterised by constant change of attitudes, relativization of everything, and increasing subjectivism. Owing to the market, technology, unpredictability of circumstances and impenetrable play of interests, the postmodern society lacks transparency. Owing to electronic media, everyone understands only fragments of messages. Television news creates an image of the world which may differ from reality. Mlčoch et al. (2000) claimed that the lack of strong and enforceable rules may create a societal schizophrenia. Expectations in such an environment are no longer based on social regularity.

According to Novy and Taylor (2014), the commonly used models are unable to explain the higher intensity of the effect of the last global recession on the international trade than on the output. They included in the model the effect of uncertainty. They could then explain a higher decline in trade compared to production by postponing orders in companies to a later time. The fluctuations in international trade are mapped with the uncertainty index of the stock market volatility. Bloom's uncertainty index understood the uncertainty perception as a secondary demand and productivity shock causing recession. Putna (2014) saw in uncertainty reason for the so-called big trade crisis. Thanks to a negative feeling about the future companies delay investment and hiring of employees. He mentions the VIX index as the "fear index". Indicators of uncertainties and risks on the markets gave him predictor of the unknown future development, and they should be commonly used with usually published data.

The first aim is to map the uncertainties in postmodern or post-industrial or information society. In addition, we aim at determining the methods which are commonly used to measure the effect of cognitive processes on decision-making and creating anomalies and uncertainties in general. We focus on developing a Central European variation of the VIX uncertainty and fear index, which will provide us with information on perceiving uncertainty among companies in the Visegrád group countries (V4 countries). We try to decide on the way of putting our psychological factor on the supply side in the standard Gordon's Triangle model which was used by Sekhon. For estimation of the NAIRU and the economic cycle we apply the Kalman filter method. Further we compare the NAIRU and the position within the economic cycle on the labour market obtained by the models without the effect of uncertainties with their values after reflecting the supply-related psychological factor.

The paper is divided in the following sections. The second part will briefly outline the development of the concepts of the relationship between inflation and unemployment. The third part divides the fundamental methods in groups and the standard model for estimating the NAIRU reflects the variable describing the supply-related psychological factor. The fourth part will introduce the description and asymmetries or paradoxes of postmodern, post-industrialist or information society. We will observe the effect and manners of measuring the effect of cognitive, emotional and motivational processes on judgment, decision-making and creating anomalies. In addition, we will define the VIX index and develop its version for the $\mathrm{V} 4$ countries. The fifth part will deal with the verification of our indirect indicators using the actual data, as well as localising five scenarios of the character of the effect of uncertainties on the labour market and quantifying this effect. The sixth part will provide a summary of the analysis results of the effect of the supply-related psychological factor on the labour market development in Slovakia, including the consequences for economic policymakers in the sense of eliminating the unfavourable effect of perceiving uncertainties among companies and supporting positive tendencies.

\section{A brief outline of the development of concepts of the relationship between inflation and unemployment}

According to Humphrey (1985), the first representatives of the relationship between inflation and unemployment include authors such as Law, Thornton, Attwood, Mill, Fischer, Tinbergen, Klein and Goldberger, or Brown and Sultan. Other representatives then include those authors who have development a modern version of the trade off between inflation and unemployment. In this context, Humphrey mentions Samuelson and Solow (1960) with their transfer of the Phillip's relationship into 
the relationship with different unemployment levels for every change in the price level. For the purposes of deriving a time series of the current inflation rate, Phelps (1967) applied the time series of aggregated employment. Friedman (1968) mentions two limitations of the currency policy arising from the impossibility to fix interest rate and the unemployment rate over a longer period of time. Modigliani and Papademos (1975) are the authors of the concept of the non-inflationary unemployment rate (hereinafter only the NIRU), which makes inflation decrease at the time when unemployment is higher. According to Humphrey the founder of the modern version of the Phillips curve (hereinafter only as "PC") is Phillips (1958), according to whom a strong curvature of the PC in the section with low unemployment leads to a lower average increase in salaries with constant unemployment than in the case of unemployment being around any such level.

The author of the concept which we used is Tobin (1997). The Non-Accelerating Inflation Rate of Unemployment (hereinafter only as the "NAIRU") is a result of macroeconomic balancing of pressures onto inflation growth on markets with excessive supply.

\section{Classifying basic methods into groups including the reflection of the supply- related psychological factor into the standard model for the NAIRU estimate}

Richardson et al. (2000) mentioned that the unobservable variable of the NAIRU needs to be quantified for economic policymakers. These authors then divide the methods for estimating the NAIRU into three basic groups. Using structural methods, the NAIRU may be obtained only in the case that markets are completely or at least partially balanced. Purely statistical techniques estimate the NAIRU so that they divide the actual unemployment rate into a trend (which in fact corresponds to the NAIRU) and the cyclical element. The methods of the reduced form obtain the NAIRU using behavioural equations and limitations of fluctuations in the NAIRU development and the unemployment gap.

For the purposes of estimating the NAIRU, McAdam and McMorrow (1999) use a simple equation of an inflation system the Gordon's "Triangle" model, as well as a system of equations of wage and price development, which is called the Bargaining model. Fabiani and Mestre (2000) perceive as purely statistical methods the Hodrick-Prescott filter (hereinafter only as the HP filter") and Baxter-King filters. The reduced form group also includes the Kalman filter, which is based on the inflation equation and assumptions of the law of variability in the NAIRU development. This group also includes the stochastic trend method (Fabiani and Mestre, 2001), estimating the NAIRU regardless of the past development of the inflation rate.

McAdam and McMorrow (1999) used for the NAIRU estimating the PC extended with expectations. The NAIRU is then a balanced unemployment rate or the unemployment rate at the permanent state (i.e. at an constant inflation rate). The NAIRU is then located at the point with the stable proportion between the deviation of unemployment from the NAIRU and unexpected inflation. The Gordon's "Triangle" model (Gordon, August 1996), which was perceived as a leading system for the NAIRU estimate by these authors, is grounded on the unemployment rate consistent with permanent expectations. The basis expression of this model consists in the triangle method in which the inflation rate is depended on inflation expectations, demand conditions represented by the unemployment gap, and supply shocks.

The applied indicators of the perception of uncertainty among companies in the V4 countries have a character of a psychological factor on the supply side and we will use the standard inflation model according to Sekhon (1999). We put the indicator of perceiving uncertainty among companies in the original group of regressors including supply shocks. For this reason, the equation of the standard inflation model remains in the following form:

$$
\pi_{t}-\pi_{t}^{e}=\beta\left(u_{t}-\bar{u}_{t}\right)+\partial X_{t}+v_{t},
$$

where $\pi_{t}=$ estimate of the actual inflation rate, $\pi_{t}^{e}=$ expected inflation rate, $u_{t}=$ unemployment rate, $u_{t}=$ NAIRU, $X_{t}=$ regressors controlling supply shocks (oil price, importation prices, exchange rate, and indicators of perception of uncertainty among companies in the V4 countries), and $v_{t}=$ error member. 


\section{The characteristics of uncertainty in postmodern society, measuring the effects of cognitive processes on decision-making and defining the indicators of the uncertainty perception among companies in the V4 countries}

This section will analyze the fundamental features of postmodern, post-industrial or information society. In addition, we will map the sources of occurrence and the character of any possible asymmetries and paradoxes occurring in society and being the source of uncertainties. We will also ascertain the effect and manners of estimating cognitive, emotional, and motivational processes on judgment, decision-making and creating anomalies and uncertainties. Due to the non-existences of measuring tools for uncertainty and concerns in Central Europe, we will define and calculate, on the basis of analogy with the uncertainty index used on American stock markets, the indicators of perceiving uncertainties among companies within the context of the V4 countries.

\section{Asymmetries and paradoxes creating uncertainties in postmodern or post-industrial or also information society}

Owing to the transition from the paradigm of awareness to the paradigm of communication, the constant rules become probably standards and conventions (Adorno et al., 2009). Media have become the most important source of reality. After all, every construction of reality is a result of culture. According to Šoltys, media communication substitutes the recipient's senses. According to Luhman, mass media are most likely to manipulate or selectively sort out information. However, the reality is perceived as presented by the media. Mass media create uncertainties, stimulation, expectations, surprises, and discontinuity. Through over-accentuating the freedom of others, while being fully aware of the boundaries of own space, mass media have extended space for decision-making and creating uncertainty.

According to Bělohradský in the work mentioned above, the commodification of words deprived them of their meaning. The human world has been made unreal by consumerism. The key values are performed merely owing to the increase in technical perfection. Permanent transformation of desire for new goods to shortage leads to the impossibility of strategic management. Owing to specialisation, the fragments of the world represent the whole. Forced technological innovations do not reflect the actual needs of society. Keller finds out that states take decisions the consequences of which they are unable to influence. Long-term effects are neglected in favour of short-term benefits. Society consists of a varied mosaic of ever-changing groups. The global competitiveness is required not only in companies, but also in the case of states and social policies.

Adorno says that the development of cultural industry is predominated by effects and technical detail over the work's ideas. The whole is not related to the detail and any further development is a consequence of an immediately preceding situation, rather than the idea. Bílek admits that only a few partial and random features of the original image are available in a mental image. The work is supposed to produce partial feelings, states of mind, which may be identified with only for a short period of time. According to Valček, language is unable to express what is generally expected. Meanings are then localised and fixed upon labelling conceptual wholes. Lapčík perceives a great danger in the fact that a new term often becomes part of the discipline's terminology even without defining its meaning and use, which is a source of misunderstanding and the extinction of discussion on legitimacy, validity, and limits of various approaches. According to Bočák, reality is a result of competition of individual social groups. According to Hubík, sign magic modifies reality which may even completely disappear.

\section{Measuring the effect of cognitive, emotional and motivational processes on decision-making and creating anomalies and uncertainties}

Breiter et al. (2001) studied judgment and decision-making with the help of the function of magnetic resonance. The experiment included a phase in which three financial amounts were introduced and a phase in which only a single amount had been selected. Reactions to proposals were then expressed in the same area of the brain and the bloodstream. Kahneman (1999) focused on the 
assessment of the moment using experiments (by means of projecting pleasant and discouraging film clips without a plot or using a vice and unpleasant sounds to convey painful and displeasing experiences). Ariely et al. (2000) examined the importance of time sequence for obtaining experience. Their experiments were based on manipulating the extensional variables (screening films or asking questions). Kahneman (2002) examined the effect of the institution on decision-making using two generic modes of cognitive functions of thinking. Kahneman and Frederick (2001) dealt with intuitive decision-making in the environment of uncertainties using the attribute substitution model of the method of attempt and error. Kahneman et al. (2011) analyzed the effect of prejudice on judgment using 12 questions for decision-makers.

Putna (2014) uses for measuring the uncertainty and concerns in the economy with the VIX uncertainty index on the stock market. This indicator is also labelled as the "fear index" and it is a measure of volatility of options prices for the S\&P 500 index. In his article, he outlines the development of the VIX index in the period of 1994 to 2014. According to the author, the Bloomberg data shows a marked increase in the uncertainty and concerns raised by the fall of Lehman Brothers in 2008. The increase in the VIX index values in March 2014 then represents an increase in the "fear and uncertainty" due to the Ukrainian crisis, future steps taken by Russian and more stringent sanctions imposed by the EU and the USA.

The VIX index measures the implicit volatility for put and call options of the S\&P 500 SPX index (http://www.investujeme.cz/vix-meric-strachu-ktery-napovi-kdy-investovat/). The options are traded on the Chicago Board Options Exchange. The index represents a market estimate of the future volatility as a weight mean of implied volatility of a wide scale of impulses (http://www.bloomberg.com/quote/VIX:IND). The VIX index develops in an inverse direction in relation to stock markets (http://www.investujeme.cz/vix-meric-strachu-ktery-napovi-kdy-investovat/). An alternative to the VIX index consists in the VXN index (based on the development of options related to the Nasdaq 100 index), the VXD index (follows the Dow Jones Industrial Average index), and the VXO index (corresponds to the development of options relate to the S\&P 100 index).

\section{Definition of the indicator of the perception of uncertainties among companies of the V4 countries}

The VIX index measures the volatility of the American S\&P 500 index, and cannot be applied onto the V4 countries. We do not have any Central European alternative to this index and we calculated own analogy. We have developed own uncertainty and fear index in relation to the stock indexes of the V4 countries. The volatility of shares and stock markets we take from the V-Lab Company. Our time series is possible used as an index of the perception of the uncertainty among companies or the indicator of the supply-related psychological factor within the Central European. Concretely for Slovakia we used the values from V-Lab Company's website (http://vlab.stern.nyu.edu/analysis/) related to the Slovakia SAX 16 index. Data represents the annual volatility in \%.

The following Figure 1 confirmed the intuitive assumption on the impossibility of applying the published data of the VIX index onto the condition of the V4 countries, as well. 
Figure 1. Development of the VIX index and the indicators of the perception of uncertainties among companies in the V4 countries.

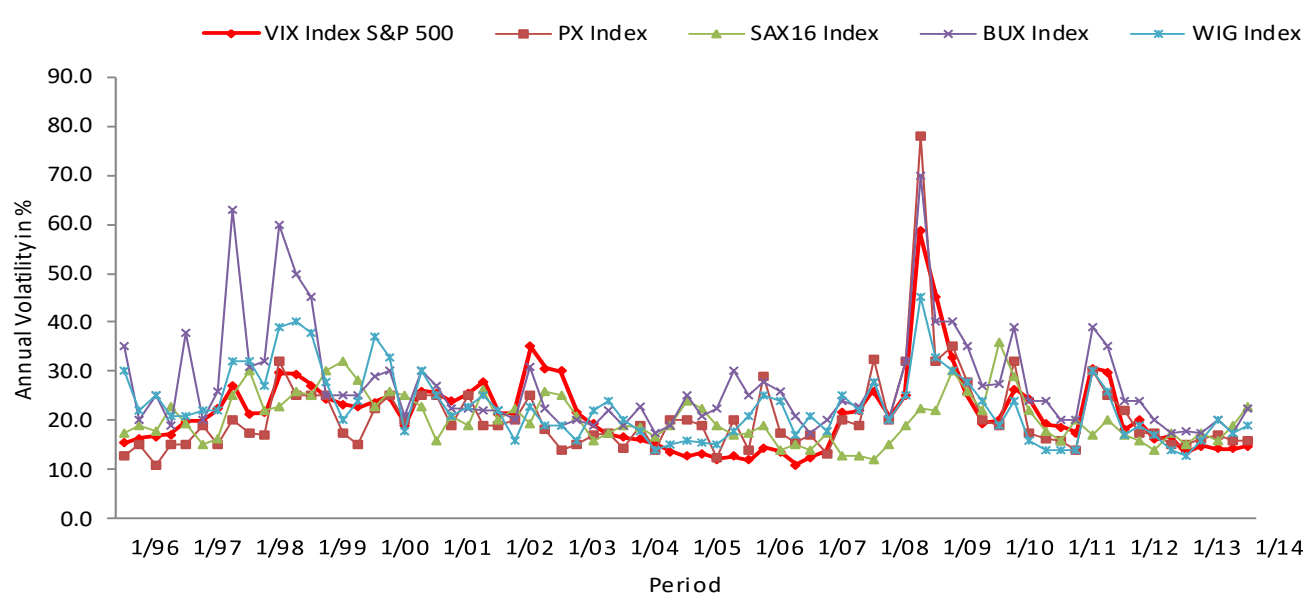

Source: Bloomberg Data and own calculation on the basis of data V-Lab.

Substantial differences between the development of the VIX index and the uncertainty perception indicator among companies in the V4 countries were localized in Slovakia. In particular, this applies to 1999, when the Central European countries were undergoing transformation from the planned social and economic system to the market economy. This was followed by the period at the turn of 2008 and 2009, when Slovakia saw a more moderate phase of the financial crisis than in the USA. The opposite situation occurred at the turn of 2009 and 2010, when Slovakia did not see such an important decrease in the uncertainty perception among companies as the US economy, with even an annual increase being found in one quarter.

\section{The effect of the uncertainty perception indicators among companies on NAIRU and economic cycled in terms of the labor market in Slovakia}

We will use the standard Gordon's "Triangle" model as adapted by Sekhon because our applied indicators of uncertainty perception among companies in Slovakia have a character of a supply-related psychological factor. We use the general applied PC concept extended with expectations. The method of the Kalman filter provides us the NAIRU variable in time (Kadeřábková and Jašová, 2012). The smoothing coefficient will be used in the amount of 0.6. This level will fit the development in transitional economies and in the period of cyclical turbulences precisely. When we subtract NAIRU from real unemployment rate, we will have the economic cycle on the labor market (as well unemployment gap) in percentage point.

Effect of the indicator of uncertainty perception among companies on the NAIRU and the economic cycle on the labour market we obtain when we compare the model without the effect of the uncertainty (to be labelled as the original model) and the model with the supply-related psychological factor (also labelled as the extended model). The Kalman filter in both models included as a dependent variable the deflator of the household consumption (an annual change in \%). In the original model and in the extended model, the explanatory variables included the delayed values of the household consumption deflator, the unemployment rate without delay in \% (the unemployment rate in $\%$ is defined by the International Labor Organization (ILO)), the annual change in the exchange rate (\%) with delay. The annual change in the Brent oil prices was not with delay in the original model and was with delay in extended model (\%). The annual change in the indicators of uncertainty perception among companies in the extended model was with delay (\%).

We map the development of indirect indicators and we have to compare our own indicators with the published indicators. This way we verify their accordance with the actual economy data. The indicator of uncertainty perception among companies we confront with data of the fixed capital. The NAIRU and economic cycle we verified by indicators of the unemployment rate and the gross domestic 
product. If the NAIRU values (in both models) grew annually in the time when the actual unemployment rate declines, there is not accordance between the models' estimates and the actual data, and the analysis results are less robust (Table 1 ).

We will assess the character of the relationship and the quantification of the intensity of the effect of the supply-related psychological factor on the labor market with five scenarios (Table 2.) too.

In the first scenario of the relationship description between the supply-related psychological factor and the labor market, the indicator of uncertainty perception remains unchanged compared to the same period of the previous year. Companies wait when creating their development plans and making investments. The unemployment rate and the NAIRU stagnate on the level of the previous year or slightly annually decline.

The second scenario implies the annual decline of the indicators of uncertainty perceptions in companies. Companies increase the investment activity and placing new orders. The unemployment rate annually declines or stagnates on the level of the previous year, and the NAIRU declines annually or grows, respectively.

In the case of the third scenario the indicator of uncertainty perceptions among companies grows annually. They postpone investment activities. The unemployment rate annually growths. The NAIRU annually increases or declines. When the NAIRU annually declines, the cyclical unemployment increases.

The fourth scenario is the so-called a general lack of trust in optimistic signals. The annual decline in the indicator of uncertainty perception does not motivate companies to hire new staff members. The unemployment rate grows annually. The annual decline in the NAIRU shows the existence of cyclical unemployment and the annual growth in the NAIRU structural unemployment.

The fifth scenario is the so-called a general negligence of pessimistic signals. The annual growth in the indicator of uncertainty perception does not make business entities be more cautious when they plan investment and hiring new staff. The actual unemployment rate and the NAIRU decline annually.

We measure the intensity of the actual effect of the estimated supply-related psychological factor on the unemployment rate, the NAIRU, and the economic cycle. We specialized on the time of structural changes, on the deep cyclical changes, and on the period after such fundamental changes (Table 3).

In the case of Slovakia, the localization revealed nine periods following the previously defined character of the relationship between the indicator of uncertainty perception among companies and the overall unemployment rate. The indicator of uncertainty perception among companies and the NAIRU were also verified using the development of actual data, which corrected the analysis conclusions on reflecting the actual effect of the psychological factor on the NAIRU and its intensity.

The first scenario did not occur in Slovakia. The second scenario (the annual decline in the indicators of uncertainty perception among companies, increasing investment activities and placing new orders, the annual decline or stagnation of the unemployment rate, and the annual decline or growth of the NAIRU) was localised in the period of Q4 2002 to Q2 2004, Q4 2005 to Q2 2008, and Q1 2011 to Q1 2013. The indicator of uncertainty perception among companies dropped annually (by $2.4 \%$ or by $2.9 \%$ and $4.7 \%$ respectively) and in the second and third period, it corresponded to the development of the fixed capital (an annual growth of $9.7 \%$ and $0.4 \%$ ). The first examined period was classified with the conditional verification status, as it consisted in more or less a stagnation of the indicator (the annual decline amounted to merely 1.1\%). Due to the fact that the original NAIRU value, as well as the value after reflecting the supply-related psychological factor grew annually in the first and second period (by $0.4 \%$ and $2.3 \%$, Figure 2 ) and that the unemployment rate declined annually (by $0.4 \%$ or $2.4 \%$ respectively), there was a contradiction between the model's estimate and the actual data. Whereas in the first case the status of the conditional verification may be awarded due to the practical NAIRU stagnation, the second period could result in distorted conclusions of the analysis. In the third period, the NAIRU estimate already corresponded with the development of the unemployment rate (the annual decline amounted to $1.6 \%$ or $0.1 \%$ respectively). The decline in the uncertainty perception in the economy was reflected in the NAIRU value in all the periods (the 
conclusion is only indicative for the second period), as the annual increase (in the first and second period) or decline (in the third period) of the NAIRU value estimated after incorporating the supplyrelated psychological factor was lower (or higher) than in the case of the values taken from the original models (by $7.1 \%$ or $0.2 \%$ and $4.2 \%$ respectively).

Figure 2. Development NAIRU according to the original model and its enlargement on psychological factor on the supply side in Slovakia.

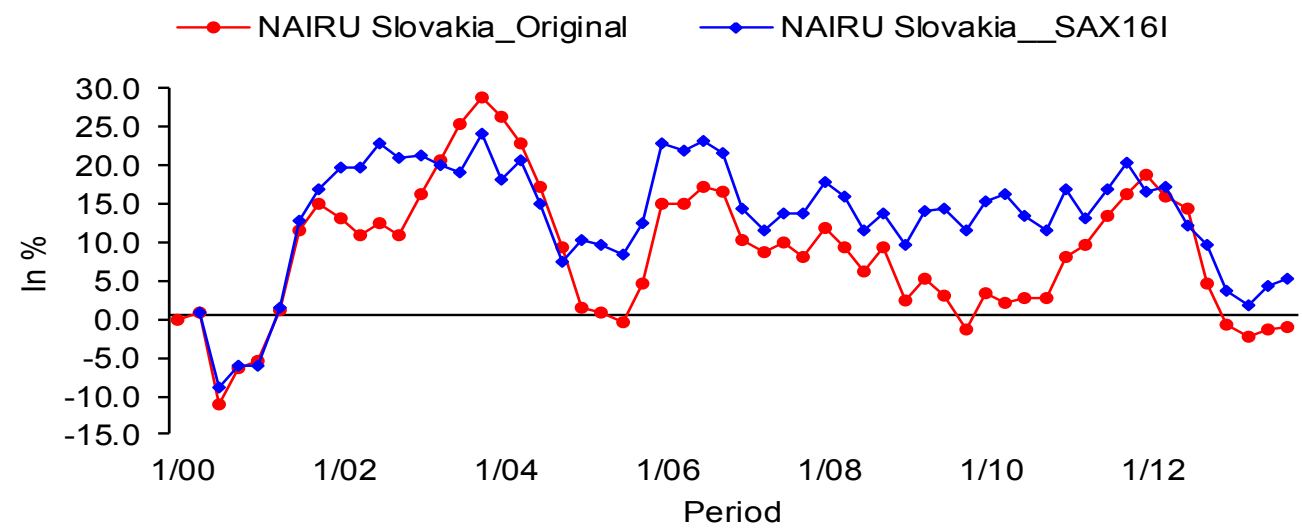

Source: Own calculation based on data from the OECD and the VLab.

The third scenario (the indicators of uncertainty perception among companies grow annually, companies postpone their investment activities, the unemployment rate increases annually, and the NAIRU shows an annual increase or decline) was localised in the period of Q3 2008 to Q3 2009, Q4 2009 to Q4 2010, and Q2 to Q4 2013. The indicator of uncertainty perception among companies saw an annual increase (of $9.5 \%, 0.9 \%$ or $1.6 \%$ respectively), whereas the fixed capital declined annually only in the first and third period mentioned above (by $14.7 \%$ and $1.9 \%$ respectively). Owing to the impossibility to demonstrate the correspondence between the indicator of uncertainty perception among companies and the fixed capital, the second period cannot be considered as suitable to be included in the valid analysis conclusions. The original NAIRU value, as well as the value after reflecting the supply-related psychological factor declined annually in the first period (by $3.7 \%$ or $1.8 \%$, by $1.9 \%$ and $13.2 \%$, or $9.0 \%$ respectively) with the annual increase in the unemployment rate (of $1.1 \%, 2.4 \%$ and $0.4 \%$ ), which thus revealed the presence of cyclical unemployment (and structural unemployment in the second period). In the case of the positive verification of the indicator of uncertainty perception among companies in the second period, the uncertainty perception in the economy would be reflected in all the localized intervals in this scenario. The annual decline in the NAIRU value reflecting the supply-related psychological factor (there was an annual growth in the second period) was lower than decreasing the value taken from the original model (by $1.9 \%$ or 2.7 and $4.2 \%$ respectively).

The fourth scenario (the so-called first extreme case of the general lack of trust in optimistic signals, when the unemployment rate grows annually and the NAIRU declines or grows) was identified in the period of Q1 to Q3 2001. The indicator of uncertainty perception among companies saw an annual decline (of 5.9\%) and the fixed capital grew annually (by 15.3\%), which is in contradiction to the scenario definition or the verification principle, and the conclusions related to this period may only be considered as indicative. The original NAIRU value, as well as the value after reflecting the supplyrelated psychological factor grew annually (by $5.9 \%$ and $11.1 \%$ ), the unemployment rate saw an annual increase (of $0.5 \%$ ) and the economy was experiencing structural unemployment. In the case of the positive verification of the indicator of uncertainty perception among companies, its negative effect would not be reflected as the annual growth of the NAIRU value reflecting the supply-related psychological factor was higher than the growth of the value taken from the original model (by $5.2 \%$ ). 
The fifth scenario (the so-called second extreme case of the general neglect of pessimistic signals in the economy and society, and the annual decline in the unemployment rate and the NAIRU) was localised in the periods of Q4 2001 to Q3 2002 and Q3 2004 to Q3 2005. The indicator of uncertainty perception among companies saw an annual increase (of $2.3 \%$ and $2.7 \%$ ) and the fixed capital grew annually (by $1.9 \%$ and $13.7 \%$ ); both periods thus correspond to the scenario definition. In the first period, the original NAIRU value, as well as the value after reflecting the supply-related psychological factor, increased annually (by $12.7 \%$ or $19.3 \%$ respectively), with a decline in the unemployment rate (of $0.3 \%$ ), which does not allow recognising the positive verification and using the conclusions related to this period in the final evaluation of the analysis results. In the second period, both the NAIRU and the unemployment rate declined annually (by $18.5 \%$ or $9.3 \%$ and $1.2 \%$ respectively), so the economy was experiencing cyclical unemployment. The NAIRU development saw the general neglect of pessimistic signals in the economy occurred in both analysed periods, as the annual increase or decrease of the NAIRU value reflecting the supply-related psychological factor was higher (or lower) than the increase (or decrease) in the value taken from the original model (by $6.6 \%$ or $9.2 \%$ respectively).

Figure 3. Development of the unemployment gap according to the original model, and after its expansion to include psychological factor on the supply side in Slovakia

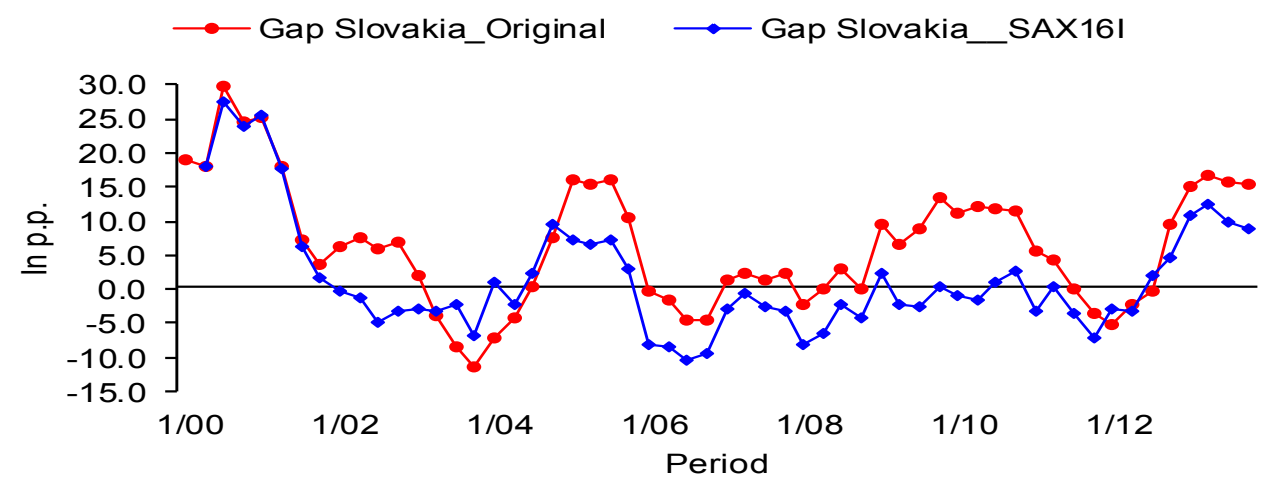

Source: Own calculation based on data from the OECD and the V-Lab.

In relation to the application of five scenarios defining the character of the relationship and intensity of the effect of the indicator of uncertainty perception among companies on the economic cycle, we will evaluate five periods.

Within the second scenario (an annual decline of the indicators of uncertainty perception among companies, increasing the investment activities and placing new orders among companies, an annual decline or at most a stagnation of the unemployment rate, and the annual decline or growth of the NAIRU), there will be two periods analyzed. The period of Q1 to Q4 2006 saw large positive gaps on the labor market (9.0 p.p., Figure 3 ). The indicator of uncertainty perception among companies declined annually (by 4.3 p.p.) and the fixed capital grew annually (by $9.4 \%$ ). Even though the unemployment rate in the examined period declined annually (by 2.9 p.p.) and the NAIRU increased (by 14.4 p.p. or 12.1 p.p. respectively), this contradiction will not be deemed as the verification failure owing to the practical stagnation. A lower intensity of uncertainty perception among companies was reflected in the development of unemployment gaps so that the positive gaps grew (by 6.3 p.p.), while at the same time, the boom phase was substantially extended.

The second period in this scenario consisted in the interval of Q4 2011 to Q3 2012, which was characterized by the phase of a short boom immediately following the recession. As the indicator of uncertainty perception among companies declined annually in this period (by 1.0 p.p.) only due to a non-standard fluctuation in one quarter, the annual decline of the fixed capital (of 3.7\%) will not be deemed as a contradiction in the development of both variables. On the other hand, even though the 
unemployment rate declined annually, the actual decline amounted to merely $0.2 \%$, and for this reason the accompanying annual NAIRU growth (of 7.9 p.p. or 1.8 p.p. respectively) will be deemed as meeting the condition of the positive verification. A lower intensity of uncertainty perception among companies was not reflected in the size of the unemployment gap, as it remained unchanged even after the extension of the original model with the uncertainty indicator. Nevertheless, the period of the positive phase was extended with two periods.

The third scenario (the indicators of uncertainty perception among companies grow annually, the unemployment rate grows annually, and the NAIRU experiences an annual increase or decline) is also associated with two periods. This includes the period of Q1 2009 to Q3 2011, when the labor market was hit by the financial and economic recession. In the examined period, the unemployment rate grew annually (by 1.6 p.p.) and the NAIRU stagnated on the level of the previous year. The indicator of uncertainty perception among companies grew annually (by 0.2 p.p.) and the fixed capital dropped (by $0.7 \%$ ). A higher intensity of the uncertainty perception among companies was not reflected in the size of unemployment gaps (after incorporating the effect of uncertainties, it even switched from a negative value to a positive one), and the recession period also got shorter (by three quarters).

The second period includes the interval of Q4 2012 to Q4 2013, in which the labor marker experienced the second recession bottom. In this period, the unemployment rate grew (by 0.6 p.p.) and the NAIRU declined annually (by 14.2 p.p. or 10.1 p.p. respectively). The indicator of uncertainty perception among companies grew annually (by 0.1 p.p.) and the fixed capital declined (by $6.2 \%$ ). A negative effect of a higher intensity of uncertainty perception among companies was not reflected in the development of the unemployment gap, as the original gap value was 5.1 p.p. lower. Nevertheless, the recession phase was extended with one quarter.

Within the fourth scenario (a general lack of trust in optimistic signals, an annual decline in the indicators of uncertainty perception, an annual increase in the unemployment rate, and the annual decline of the NAIRU, or its annual growth), it is possible to analyze the period of Q1 2000 to Q2 2001. In this period, the labor market was undergoing the economic transformation following the change of the political and economic system. Due to the fact that only limited data base was available for the analysis purposes, the conclusions on the beginning of this cycle phase must be deemed less robust. The indicator of uncertainty perception among companies declined annually (by 5.0 p.p.) and the fixed capital also decline in accordance with the definition of this scenario (by $0.5 \%)$. In the examined period, the unemployment rate grew annually (by 1.8 p.p.) and the NAIRU annually grew or declined (by 2.6 p.p. or 0.6 p.p. respectively). A negative effect of the general lack of trust in optimistic information was reflected so that the original negative unemployment gap rose after incorporating the uncertainty (by 0.2 p.p.), and the phase of the transformation recession was extended with two quarters, as well.

\section{Conclusions from the theoretical and empirical parts and consequences for economic policymakers}

At first, we described the characteristics of uncertainty in postmodern or post-industrialist or so-called information society. According to Bělohradský (2013), the market and technology made postmodern society non-transparent, electronic media made people's live non-transparent, and television, through its selection of news, creates an image of the world different from reality. Fama (1997) finds out that long-term anomalies are accidental results of exaggerated or insufficient reactions to information. According to Kahneman (2002), it is necessary, in some cases, to correct intuitive decision-making; nevertheless, intuition will always play a crucial role in decision-making. Novy and Taylor (2014) have found out that commonly used model are unable to explain a higher intensity of the effect of global recession on international trade than on the output. According to Putna (2014) there could also be uncertainty behind the so-called big trade crisis.

The article aims at creating a Central European alternative to the VIX index of uncertainty and fear in America. As a measure of volatility, we use a standard deviation of the daily price of shares or the value of the share index of the V4 countries. The rightfulness of denying the automatic application 
of the VIX index in the context of V4 countries was confirmed already in the graphic representation of the VIX index development and our derived indicators of uncertainty perception among companies in V4 countries. The biggest differences were found in the case of Slovakia, particularly in 1999 (the period of economic transformation), at the turn of 2008 and 2009 (the effect of the financial crisis was milder in Slovakia than in the USA), and in the period following the recession (Slovakia saw a milder decline in the level of uncertainty perception among companies than the US economy, and even its annual increase in one quarter).

As our applied indicators of uncertainty perception among companies in V4 countries have a character of the supply-related psychological factor, we used the standard Gordon's Triangle model for inflation in the original wording as introduced by Sekhon. The indicators of uncertainty perception among companies in V4 countries were associated with the existing group of regressors controlling supply shocks.

Before conducting a detailed analysis of the relationship between the development of corporate uncertainty and the labour market, the indicators introduced by us we subject to further comparison (verification) with the development of adequate indicators which are commonly officially published (Table 1). In the case of the indicator of uncertainty perception among companies, thus consisted in the verification using a time series of the annual change in the fixed capital. In Slovakia, this also consisted in two periods in which the development of the indicator of uncertainty perception among companies was not verified by the fixed capital (the total number or periods was 9). Owing to an established non-representativeness of the reasons for the different trend in the development of the fixed capital compared to the supply-related psychological factor in one period, the original rejecting conclusion was reconsidered as sufficient and awarded with the status of conditioned conformity. In the case of the labor market, our estimate of the NAIRU development was verified by means of a time series of the unemployment rate. In Slovakia, there were only two cases of inconsistency found between the NAIRU development and the actual unemployment rate.

When analyzing the character of the relationship and intensity of the supply-related psychological factor on the unemployment rate and its components, five possible development scenarios were discovered (Table 2 and Table 3).

In the first scenario, the indicators of uncertainty perception among companies remain unchanged compared to the same period of the previous year, companies are postponing taking decisions on new development plans, the unemployment rate annually stagnates on the level of the previous year or declines annually, and the NAIRU annually stagnates or declines. The scenario was not identified in Slovakia.

The second scenario implies an annual decline in the indicators of uncertainty perception among companies, companies increase their investment activities and placing new orders, the unemployment rate declines annually or at most stagnates, and the NAIRU annually declines or rises. In Slovakia, the effect was demonstrated in all three periods, even though in one of them, this conclusion should be applied with caution owing to the negative verification.

In the case of the third scenario, the indicators of uncertainty perception among companies grow annually, companies postpone their investment activities, the unemployment rate increases annually, and the NAIRU sees an annual increase or decline at the same time. In the event of the annual decline in the NAIRU, there is an acceleration of the increase in cyclical unemployment. In Slovakia, the scenario was identified in three periods. In Slovakia, in the case of the positive verification in the second period, the negative effect of uncertainty perception was reflected in all the localized intervals in this scenario.

The fourth scenario (the so-called first extreme case of the general lack of trust in optimistic signals) implies that the annual decline in the indicators of uncertainty perception, in general, does not motivate companies to reflect them in their development plans, the unemployment rate increases annually, the annual decline in the NAIRU implies the existence of cyclical unemployment, and the annual NAIRU growth structural unemployment. In Slovakia this scenario occurred in one period. In Slovakia, in the case of the positive verification of the indicator of uncertainty perception among companies, its negative effect would be reflected in the NAIRU, though. 
In the case of the fifth scenario (the so-called second extreme case of the general neglect of pessimistic signals), the indicators of uncertainty perception among companies grow annually, yet companies do not reflect general negative news, while the unemployment rate and the NAIRU still continue to decline annually. In Slovakia, this scenario was localized in two periods. In Slovakia, the general neglect of pessimistic signals in the economy occurred in the NAIRU development in both analyzed periods (in the first one, the conclusion only has an indicative character).

In Slovakia, there was a very strong and rather negative effect of uncertainty perception on the NAIRU development (a positive effect in two periods and a negative effect in three periods).

In Slovakia, the economic policy should attempt to limit the spillover of the increasing uncertainty in the real economy sectors, as they increase the unemployment rate and the NAIRU. In Slovakia, it is necessary that the economic policy should convince companies on the practicability and perspective of optimistic signals, in support of which it is ready to apply effective measures which will overturn the still-present and unfavorable development in the real economy (e.g. the observed high unemployment rate and NAIRU). This also includes encouraging caution and reviewing the existing the investment and personnel strategy which will better take into account the potential risks. But it also includes the patient explanation of the essence and effects of the planned supporting measures which will minims the effects of instability.

The first scenario was not located to the character of the development of the phases of the economic cycle in Slovakia. The second scenario occurred in two periods in Slovakia. In terms of the phases with which we eventually associated these scenarios, it consisted mainly in the phase of a short boom immediately following the recession (Slovakia). In Slovakia we speak about the period with large positive gaps on the labor market. In terms of the actual reflection of the positive effect of uncertainty perception among companies on the unemployment gap, it may be stated that it was established only in the case of Slovakia. In the first period (the period with large positive gaps on the labour market), a lower intensity of uncertainty perception among companies increased the positive unemployment gaps, while there was also a significant extension of the boom phase. In the second period (the short boom phase immediately following the recession), the annual decline in uncertainty perception did not change the size of the unemployment gap; nevertheless, the period with a positive phase was extended.

The third scenario copies the cycle development in two periods in Slovakia. This scenario was equally associated with the financial and economic recession. Furthermore, this also applies to a period in which there was the second recession bottom (Slovakia). In Slovakia, this applied only to the period of the second recession bottom. The negative effect did not hit directly the size of the unemployment gap but it only extended the length of this negative phase.

The fourth scenario corresponds to the cycle development in one period in Slovakia. This scenario was associated with the economy transformation after the change of the political and economic system, the recession phase, and the second recession bottom, and there recession phase representatives were localized always in two countries. The actually demonstrable negative effect of the general lack of trust in optimistic signals was reflected in the development of the unemployment gaps in Slovakia. In all three forms of recession, increasing the uncertainty perception among companies was reflected in the annual growth of the negative unemployment gaps. Furthermore, Slovakia also experienced the extension of this phase. The fifth scenario was not associated with Slovakia.

In Slovakia, there is a prevailing strong effect of this factor on the unemployment gaps, which has a positive character in two cases and a negative character in two cases.

In the case of the economic cycle in Slovakia, we found out room for the economic policy mainly in the period immediately following the recession, when the decline in the uncertainty perception among companies in the economy was not reflected in reducing the negative unemployment gap, or the positive gap closed and the boom phase length became shorter. The same effect of increasing the uncertainty perception on the unemployment gap was also demonstrated in 
Slovakia at the time of the second recession bottom. Owing to a general lack of trust in optimistic signals, it was impossible to prevent the transfer of the increased negative gap at the time of the economy transformation after the change of the political and economic system in Slovakia.

\section{Annexes}

Table 1. Verification Result of the Indicator perception of uncertainty among companies and NAIRU respectively the economic cycle (the number of periods)

\begin{tabular}{|c|c|c|c|c|c|c|c|}
\hline \multirow{2}{*}{$\begin{array}{l}\text { Member country } \\
\text { of V4 }\end{array}$} & \multirow[b]{2}{*}{ Number of analysed periods in individual categories } & \multicolumn{3}{|c|}{$\begin{array}{l}\text { The indicator used to verify when } \\
\text { analysing the NAIRU }\end{array}$} & \multicolumn{3}{|c|}{$\begin{array}{l}\text { The indicator used to verify when } \\
\text { analysing the business cycle }\end{array}$} \\
\hline & & $\begin{array}{l}\text { Fixed } \\
\text { capital }\end{array}$ & $\begin{array}{l}\text { Unemploym } \\
\text { ent rate }\end{array}$ & Total & $\begin{array}{l}\text { Fixed } \\
\text { capital }\end{array}$ & $\begin{array}{l}\text { Unemploym } \\
\text { ent rate }\end{array}$ & Total \\
\hline \multirow[t]{5}{*}{ Slovakia } & & & & & & & \\
\hline & Total & 9 & 9 & 9 & 5 & 5 & 5 \\
\hline & Compliance / Verification & 6 & 6 & 4 & 4 & 3 & 3 \\
\hline & Conditionally compliance /verification & 1 & 1 & 1 & 1 & 2 & 2 \\
\hline & The discrepancy in the development of both time series & 2 & 2 & 4 & 0 & 0 & 0 \\
\hline
\end{tabular}

Source: Own calculation based on data from the OECD and the V-Lab.

Table 2. The number of periods with verification and with demonstrated the influence of psychological factors on the supply side (the number of analysed period)

\begin{tabular}{|c|c|c|c|c|c|}
\hline \multirow[t]{2}{*}{$\begin{array}{l}\text { Member country } \\
\text { of } \mathrm{V} 4\end{array}$} & \multirow[b]{2}{*}{\begin{tabular}{|l} 
Ranking \\
scenarios
\end{tabular}} & \multicolumn{2}{|c|}{ Number of period with verification } & \multicolumn{2}{|c|}{$\begin{array}{l}\text { Number of periods with a proven } \\
\text { effect of psychological factors on the } \\
\text { supply side }\end{array}$} \\
\hline & & $\begin{array}{l}\text { Analysis of the } \\
\text { NAIRU }\end{array}$ & $\begin{array}{l}\text { Analysis of the } \\
\text { economic cycle }\end{array}$ & $\begin{array}{l}\text { Analysis of the } \\
\text { NAIRU }\end{array}$ & $\begin{array}{l}\text { Analysis of the } \\
\text { economic cycle }\end{array}$ \\
\hline Slovakia & $\mid \begin{array}{l}1 \\
2 \\
3 \\
4 \\
5\end{array}$ & $\begin{array}{l}0 \\
2 \\
2 \\
0 \\
1\end{array}$ & $\begin{array}{l}0 \\
2 \\
2 \\
1 \\
0\end{array}$ & $\begin{array}{l}0 \\
2 \\
2 \\
0 \\
1\end{array}$ & $\begin{array}{l}0 \\
2 \\
1 \\
1 \\
0\end{array}$ \\
\hline
\end{tabular}

Source: Own calculation based on data from the OECD and the V-Lab.

Table 3. Quantification of the intensity actually established the influence of psychological factors on the NAIRU and the business cycle (the number of analysed period)

\begin{tabular}{|l|l|l|l|}
\hline \multirow{3}{*}{$\begin{array}{l}\text { Member country } \\
\text { of V4 }\end{array}$} & & $\begin{array}{l}\text { Indicator used } \\
\text { to verify when } \\
\text { analysing the } \\
\text { NAIRU }\end{array}$ & $\begin{array}{l}\text { Indicator used } \\
\text { to verify when } \\
\text { analysing the } \\
\text { economic } \\
\text { cycle }\end{array}$ \\
\cline { 3 - 4 } & Number of analysed periods in individual categories & Fixed capital & Fixed capital \\
\hline Slovakia & $\begin{array}{l}\text { Total number of periods } \\
\text { Number of verified periods } \\
\text { Number of periods with a proven impact of psych. factor }\end{array}$ & 5 & 5 \\
\hline
\end{tabular}

Source: Own calculation based on data from the OECD and the V-Lab.

\section{References}

[1] Adorno, T. W., Bělohradský, V., Bílek, P. A., Bočák, M., Burešová, Z., Horkheimer, M., Hubík, S., Keller, J., Lapčík, M., Luhmann, N., Šoltys, O., Valček, P. (2009), Spektákl, mizející realita a (ne)bezpečí informací diskurs(y) o diskursu. Kultura, média, komunikace. Centrum kulturních, mediálních a komunikačních studií, Univerzita Palackého v Olomouci. Svazek I (2009), ISSN 18040365, MK ČR E 18974. 
[2] Ariely, D., Kahneman, D., Loewenstein, G. (2000), Joint Comment on „When Does Duration Matter in Judgment and Decision Making?". Journal of Experimental Psychology: General 2000, Vol. 129, No. 4, 524-529.

[3] Bělohradský, V. (2013), Mezi světy\&mezisvěty. Novela bohemika 1997. ISBN 978-80-87685-04-0.

[4] Breiter, C. H., Aharon, I., Kahneman, D., Dale, A., Shizgal, P. (2001), Functional Imaging of Neural Responses to Expectancy and Experience of Monetary Gains and Losses. Neuron, Vol. 30, 619-639.

[5] Fabiani, S., Mestre, R. (May 2001), A system approach for measuring the euro area NAIRU. ECB WP, 65.

[6] Fabiani, S., Mestre, R. (March 2000), Alternative measures of the NAIRU in the euro area: estimates and assessment. ECB WP, 10.

[7] Fama, E. F. (1997), Dissecting Anomalies. The Journal of Finance, Vol. LXIII. No. 4. 1653 - 1678.

[8] Friedman, M. (1968), The Role of Monetary Policy. The American Economic Review, 58: 1-17, 7.

[9] Gordon, R. J. (August 1996), The Time-varying NAIRU and its Implications for economic Policy. National Bureau of economic Research. Cambridge.

[10] Humphrey, T. M. (September/October 1985), The early History of the Phillips Curve. Economic Review. Federal Reserve Bank of Richmond, 18-23.

[11] Kadeřábková, B., Jašová, E. (2012), Comparing NAIRU and economic cycle from the perspective of labour market in the countries of the Visegrad Group. Economic Studies journal, Bulgarian Academy of Sciences - Institute of Economics, Sofie, Bulharsko, 7, 16, 17.

[12] Kahneman, D., Lavallo, D., Sibony, O. (2011), Before You Make That Big Decision .... Harvard Bussines Review.

[13] Kahneman, D. (2002), Maps of bounded rationality: A perspective on intuitive judgment and choice. Princeton University, Department of Psychology, Princeton, NJ 08544, USA.

[14] Kahneman, D., Frederick, S. (2001), Representativeness revisited: Attribute substitution in intuitive judgment. Heuristics of Intuitive Judgment: Extensions and Applications, Cambridge University Press, New York.

[15] Kahneman, D. (1999), Evaluation by Moments: Past and Future. Princeton University, Department of Psychology, Princeton, USA.

[16] McAdam, P., McMorrow, K. (1999), The NAIRU Concept - Measurement uncertainties, hysteresis and economic policy role. 3.

[17] Mlčoch, L., Machoni, P., Sojka M. (2000), Ekonomické a společenské změny v české společnosti po roce 1989/alternativní pohled/. Univerzita Karlova v Praze, Nakladatelství Karolinum, ISBN 80-2460119-2.

[18] Modigliani, F., Papademoc, L. (1975), Targets for Monetary Policy in the Coming Year. Brookings Papers on Economic Activity, Brookings Institution. Washington, D.C., 142.

[19] Novy, D., Taylor, A. (2014), Uncertainty and the Great Trade Collapse: New evidence. VOX.

[20] Phelps, E. S. (August 1967), Phillips Curves, Expectations of Inflation and Optimal Unemployment Over Time. Economica, 254.

[21] Phillips, A. W. (1958), The relationship between unemployment and the rate of change of money wages in the United Kingdom 1861-1957. Economica, 284.

[22] Putna, M. (2014), Velká obchodní krize: je nejistota vysvětlením? Patria Online.

[23] Richardson, P., Boone, L., Giorno, C., Meacci, M., Rae, D., Turner, D. (2000), The concept, policy use and measurement of structural unemployment: estimating a time varying NAIRU across 21 OECD countries. OECD WP, 38.

[24] Samuelson, P. A., Solow, R. M. (May 1960), Analytical aspects of Anti-inflation Policy. American Economic Association, 127.

[25] Sekhon, J. S. (1999), Estimation of the Natural Rate of Unemployment: 1955:01-1997:12. Harvard University, Berkeley.

[26] Tobin, J. (1997), Supply Constraints on Employment and Output: NAIRU versus Natural Rate. Cowles Foundation Paper 1150. Yale University, New Haven, $1003 \mathrm{~B}$. 